\title{
RELIABILITY AND VALIDITY IN QUALITATIVE RESEARCH WITHIN EDUCATION IN
} AFRICA

By Birgit Brock-Utne, Professor at the Institute for Educational Research, University of Oslo, Norway.

\begin{abstract}
"We Africans need to come back to ourselves as a people. It is only the African who knows best how he can describe and manipulate his circumstances, his environment. The real thing has to start from here. The questions must be asked here. You can help us ask the questions if you like, but the answers are here. In
\end{abstract} Africa."

The above quotation stems from Carol Opok, a trainer of change agents in Uganda. The words were uttered in a tv interview sent on Norwegian television in August 1995. Here she addressed development workers from the North. She could also have addressed researchers from the North defining the questions to be researched and the answers to be given to African problems.

Jerome Kirk and Marc Miller in their booklet on "Reliability and Validity in Qualitative Research" maintain that:

"Asking the wrong questions actually is the source of most validity errors. Devices to guard against asking the wrong question are critically important to the researcher. (Kirk and Miller, 1986:30)

This essay will discuss the problems of validity and reliability in qualitative research within education and attempt to relate this discussion to Africa. Even though I shall strive to write from an Afro-centric viewpoint I am well aware of the fact that even my love for Africa, my knowledge of the swahili language and many years of living in Africa do not make me an African.

\section{The voice of Africans.}

The African researcher knows his/her environment better than any expatriate knows it and will be more likely to ask the right questions provided that $\mathrm{s} /$ he is allowed to ask them and not forced to work with questions of concern to western donors and provided that s/he trusts her/his own experiences and uses those to form concepts instead of merely transferring concepts formed in the West and based on experiences in the northern hemisphere. Abu-Loghod (1991) puts it this way: 

"Women,blacks, and people of most of the non-West have been historically constituted as
others in the major political systems of difference on which the unequal world of modern
capitalism has depended. ... being studied by "white men"...turns into being spoken for by them.
It becomes a sign and instrument of their power." (Abu-Lughod,1991:142-143)

In the Handbook of Qualitative Research edited by Norman Denzin and Yvonna Lincoln (1994) John Stanfield II discusses the work in the area of qualitative research that has been shaped by Eurocentric biases. He is himself an Afro-American sociologist with extensive research experiences in AfroAmerican and African institutions and communities. This does, however, not make him into an African. But like me he wants to take up the challenge from Carol Opok and help to ask the questions. Maybe we shall be able to counteract some of the tendency of African researchers to rely on western sources and assist them in asking questions built on their own experiences and environment. Allow me a concrete illustration at this point.

Some years ago while working at the University of Dar es Salaam a colleague of mine wanted to write a paper on the albino children in Tanzania. As a good researcher with a traditional training she went to do a library search since there was no time and no money for a larger empirical study.

The question she seemed to ask herself was: "What do the books in the library of the University of Dar es Salaam have to tell us about the albino children of Africa?" In the library she found American differential psychology books which treated the phenomenon of albinism. She found some useful information about genetic causes but the books did nothing to discuss living as an albino in the southern hemisphere. So therefore she did not put anything about that into the paper. She had no sources that covered such a phenomenon. She tried to make the paper African through the sources she could find about the albino children in Africa. These sources were written by western anthropologists from their view-point and described how albino children had been looked at as devils in some tribes and killed right after birth or as creatures to be honoured and given prominence in other tribes. The western bias was clear in the descriptions but my colleague did not have the time to do research herself around in the country to interview elders in various tribes about their views on albino children and of the treatment such children were and had been subjected to. So her paper became a mixture of these anthropological sources from the West and the American textbooks on albinism.

I knew that this colleague happened to have two albino sons herself. She felt, however, that drawing on her own experiences with them, was not "scientific", that she would be accused of being subjective. She did not dare to let her own experience speak through her own voice, to break the silence surrounding women's experiences. 
In an article called: "The Validity of Angels" the feminist scholar Patti Lather (1995) relates that within the little work that does exist on narrative inquiry into the lives of persons with AIDS women's voices are largely absent. In an article dealing with the concept of voice the American curriculum specialist William Pinar (1995:1) says:

"There is a silence of women's experience and voices, the splitting off of women's lived worlds from the public discourse of education." (Pinar, 1995:1)

Janet Miller asks: "How much does it take to break silence?"

(Miller, 1982:5) It takes a lot. Maybe we as researchers from the northern hemisphere may help giving legitimation to the experiences of African researchers as the most valid knowledge there is of African living and African education.

I asked my colleague: "If you should tell me what the three most important problems for your albino sons have been, what are they?" She thought for a while and in her mind was reformulating the research question she had formally narrowed down to a library search to a more meaningful question: "What do my experiences tell me about raising albino children in Africa?" After we had discussed a while, we could group the main answers to the question into the following categories:

\section{White skin in an environment of black people.}

The fact that her sons were white while all their friends were black made them an object of teasing, often of bullying. One of the boys had had such a hard time at one school that they had to take him out of the school. Other children would be saying that their mother had been thinking of a white man when having sex with their father and cruel things like that.

In Norway for instance albino children do not look very differently from blond Norwegian children in the winter-time. They are not immediately branded as different-looking.

\section{The amount of sun in the southern hemisphere.}

Secondly the fact that the sun was shining all day the year round could make life a torture for these children. Especially waiting for the bus to go to school could be painful. They sometimes had to wait for a long time and there was no shade where they were waiting.

The textbooks written in the North do not discuss this phenomenon. In the countries in the northern hemisphere it is cold most of the year, the sun is not up always and it is easy to hide from it. When you are an albino, it is exceedingly more comfortable to grow up as a Norwegian than as a Masaii. 


\section{The poverty of the South.}

Thirdly - the poverty of university staff in Tanzania made it almost impossible to get the things which would make life somewhat easier for the albino kids, sun-screening lotion with a strong factor, longsleeved shirts, caps, glasses.

These three problems had, however, not been discussed in her paper because she did not find them described in any literature and did not think that a scientific and scholarly paper, which was going to count towards promotion, could build on her own personal experiences. I was trying to convince her that putting herself and her own experiences into the paper was not unscientific. On the contrary - her lived experience through many years could be analyzed and were the most valid and reliable data she could find. Building on them would be describing African experience from an African view-point and would be to add to the knowledge base an indigenized perspective which was sorely needed.

Qualitative research is holistic, in the sense that it attempts to provide a contextual understanding of the complex interrelationships of causes and consequences that affect human behaviour. In doing so it seeks to avoid both the deliberate manipulation of variables (characteristic of the experimental tradition of educational research) and the study of attitudes or indicators as variables isolated from the wider totality (characteristic of the survey tradition). A further consequence of this holistic emphasis is that qualitative research tends to incorporate a wide variety of specific research techniques, even within one research project (Vulliamy, Lewin and Stephens, 1990)

\section{Researching your own society through qualitative methods.}

Vigdis Stordahl (1994) has done anthropological research on the Sami population, the indigenous people of the north of Norway. She is herself a Sami and discusses the reaction of her own people to having her as a researcher among them. She relates that most of the time the reaction from her Sami friends has been: "At last someone from our own people doing research on us and not only foreigners." She relates that she experiences a clear expectation that she will bring forth a new understanding, an understanding they will recognize and which is the "duohtavuohta" (the truth). But she also warns against culture blindness.

Culture blindness is a phenomenon which has to do with the fact that you may become blind to what you experience every day. It is difficult to go from being a participant to being an observer. And if you succeed in becoming an observer it may also be difficult to "switch off." (Stordahl,1994)

She realizes that she is not an average "Sami". Her many years of study and her training as an anthropologist make her see things from a certain position. The truth she finds will be a "positioned 
truth."

This also holds true for African researchers who have spent many years of their life unlearning the presuppositions they brought from their home environment to school and becoming westernized in outlook. In an article discussing this fact Staf Callewaert (1994), who has done extensive research in Namibia, Mozambique and Guinea-Bissau, tries to explain why one seldom finds African researchers questioning Western schooling as such:

"As a rule you cannot expect the educated African to use much energy to reconstruct and problematize the break, by which he or she became exactly what they are: educated in a modern Western sense of the word." (Callewaert 1994:108)

Rewriting research on Africa - the need for secondary analysis If Africa is going to build an education on her own roots, it may be necessary to reanalyse research on Africa which was originally undertaken by expatriates. There is abundant information on African traditional education in works of European travellers and American and European anthropologists.

But this information is often written from a biased view-point and needs a reanalysis based on oral literature from the elders in Africa.

Because so much of what is written on African tradition is written by western anthropologists and travellers, the methods of secondary research are needed when doing research from an African viewpoint. In his book on methods of doing secondary research David Stewart (1984) holds that secondary analysis may provide higher-quality data than could be obtained with a new research project, especially when the time to conduct the research is limited. The disadvantage of secondary data is that they are by definition, old data, they may have been collected for a different purpose and from a different background.

According to David Stewart (1984) there are certain questions which have to be asked by researchers making a secondary analysis of primary sources. These are questions like: Who was responsible for collecting the information? What information was actually collected? How consistent is the information with other information?

The European travellers whose reports are summarized by Theal (1910) in three volumes had, according to Ocitti (1990), a tendency of viewing indigenous African education as a phenomenon which was confined to the puberty years and achieved mainly through the rites of circumcision. Ocitti (1990) mentions that one finds a lot of parochialism and prejudices towards Africans and their 
traditional systems of education by some of the writers from outside Africa. All this information seems to have been gathered more out of curiosity than out of any intention of using it as a point of departure for the construction of school curricula.

A lot of the indigenous education in Africa went on and is still going on through the use of oral literature like riddles. (see Brock-Utne, ed. 1994)

In swahili the sign that a riddling activity is about to start is the magic word: "kitendawili" (the riddle). The person who speaks this word indicates that s/he has a riddle to tell and asks for the attention of the listeners. The correct answer to: "kitendawili" is : "tega" (set it). When the audience says "tega", they imply that they are now ready to listen and to concentrate on trying to find the answer to the riddle. The riddles were and still are of great educational value. They were meant to teach the child about manners, cleanliness and general conduct.

But the riddles are also constructed in such a way that they teach the child logic and abstract reasoning. The art of riddling is known by most East-Africans, the old riddles are still taught to children and new riddles are created. In fact the study of riddles ought to be a part of any teacher training in Africa. Some of my students in social psychology at the University of Dar es Salaam collected riddles from their own neighbourhoods and came up with impressive pieces of original research.

For instance J.M.R.Ishengoma (1988), himself a Mhaya, wrote an interesting term paper called: "Riddles as an agent of socialization and social learning among the Haya children." Having collected a vast amount of riddles still in use in Bukoba, Ishengoma analyzed the riddles as to their educational value. He found that they could be meaningfully divided into the following categories;

a. Riddles instructing children to compare, contrast and distinguish objects.

b. Riddles promoting mastery of Luhaya and proper communication skills.

c. Riddles teaching cultural norms.

d. Riddles instructing about work, agriculture and animal husbandry.

e. New Riddles.

He also found a category of riddles referring to sexual organs. These riddles are, according to Ishengoma, only asked in the company of friends or age mates of the same sex and never in the presence of adults.

Through his many examples he demonstrates what a useful tool riddles must have been, and partly 
still are, in the education of the young. He argues against western social anthropologists like Finnegan (1970) who looked at riddles as a form of entertainment and amusement for children.

Ishengoma found in his study that children coming from families where riddling was still a normal practice had a better developed vocabulary in Luhaya (Kihaya) and were more sensitized to the cultural norms of the Bahaya than children in families where the art of riddling had been ignored or abandoned such as in devoted Christian families. He claims that in many Christian families the practice of riddling is looked at as heathen.

Ishengoma with his African background was able to ask the right questions when he collected his data, namely the questions: What is the educational value of the riddling activity? What is learnt through it? The way he has collected his data makes it easy for educational planners to answer the question: How can the riddling activity be used to build an education rooted in African daily experiences?

The expatriates looking at riddling as an exotic type of folklore comparing the activity to activities they found in the west and therefore branding it as amusement were not able to ask the right questions and were thus lowering the validity of their work.

\section{Reliability and validity within qualitative research}

It has been an exception, rather than the rule, that a qualitative research report includes a discussion of the reliability and validity of the results. According to Steinar Kvale (1993) the lack of such a discussion seems to indicate that there seems to be no problem of reliability and validity within qualitative research. This, of course, is not true. The questions of validity and reliability within research are just as important within qualitative as within quantitative methods though they may have to be treated somewhat differently. The commonly held assumption that qualitative methods pay attention to validity and not to reliability is false. We shall return to this assumption.

There have been writers who urge for a combination of qualitative and quantitative approaches. In an article the Norwegian psychologist Finn Tschudi discusses whether there are different criteria by which to judge validity and reliability in the two approaches and argues that there are not (Tschudi, 1988:130) What is important is the fallibility of any method.

Indeed there is a reason to question the soundness of the whole dichotomy between qualitative and quantitative research. The authors of a book called "Mixing Methods: Qualitative and Quantitative Research" (Brannen,1992) have the ambition to break down this dichotomy. One of the authors in the 
book Martyn Hammersley (1992) expresses himself this way:

"In this chapter I want to challenge the widely held assumption that there are two methodological paradigms in social research: the quantitative and the qualitative.

This idea seems to have become a matter of consensus over the past few years among many who see themselves on one side of this divide or the other (and even among some who wish to sit astride it). I shall argue, however, that the distinction between qualitative and quantitative is of limited use and, indeed, carries some dangers." (Hammersley, 1992:39)

The Norwegian educational researcher Svein Østerud (1995) finds that if we deconstruct the dichotomy between qualitative and quantitative research and admit that each research project can be placed somewhere along a scale from an extremely qualitative to an extremely quantitative design, the question of reliability is a relevant question to ask all the way.

The language of everyday conversations contains a broad conception of reliability and validity. In ordinary speech, "valid" refers to the truth and correctness of a statement. An argument may be considered valid, strong and convincing, or invalid and illegitimate. A person may be described as reliable, dependable and trust-worthy.

\section{Reliability within qualitative research}

We shall start the discussion of the use of the concepts reliability and validity within qualitative educational research with the least important of the concepts, the concept of reliabity. A concept which some researchers see as superfluous, others as belonging to a quantitative tradition.

Egon Guba and Yvonna S.Lincoln (1994) see the concept of reliability as a criterion by which to judge qualitative research as belonging to the positivist or postpositivist paradigm. They mention that those working from a constructivist paradigm would prefer the concept "dependability." We shall nevertheless here discuss the applicability of the concept within qualitative research.

The Norwegian educational researcher Thor Arnfinn Kleven (1995) defines reliability as "relative absence of haphazard errors of measurement." (Kleven, 1995:13) He finds that some qualitative researchers seem to think that the qualitative method in itself assures reliability while other qualitative researchers seem to think that reliability within qualitative research is an unattainable and irrelevant demand. He goes through six commonly held misconceptions about the concept reliability and how it applies to quantitative and qualitative methods.

He refers to Kvale (1989:79) who holds that reliability is a question of whether repeated 
investigations of the same phenomenon will give the same result. Kleven, however, claims that high reliability in the traditional or psychometric sense of the word is no guarantee that the investigation is reliable or that a new investigation of the same phenomenon is going to give approximately the same conclusion. To be able to know something about this, we need to know something about construct validity as well as internal and external validity.

The fact that the theory of reliability has been developed within psychometry has also led to the fact that more general literature within research methods has referred to tests in their treatment of the concept.( e.g. Judd, Smith and Kidder, 1991) Kleven also admits that when almost all the examples mentioned in the literature on reliability are taken from quantitative data on an interval scale level, this may give rise to the misunderstanding that it is only in connection with quantitative data that the problem of reliability is of concern. Kleven argues for a way to define reliability so that it does not exclude large portions of the data gathered within the educational research field.

He concludes that both within qualitative and quantitative methods validity is more important than reliability. In fact he raises the question whether we need the concept reliability at all as an independent concept since the question of reliability has little relevance except in connection with the question of validity. Reliability he claims has only relevance because it is a necessary precondition for attaining validity. This applies equally well for quantitative data as for qualitative data. The only difference exists in the fact that within the qualitative tradition one often overlooks the threat to validity of the data which has to do with an insufficient concern for reliability.

In textbooks in psychometry the types of errors which lead to low reliability are grouped in conditions having to do with the test situation, conditions connected to the researcher, conditions having to do with the test person in the test situations and conditions having to do with the test itself (e.g.Rand, 1971:55).

Kleven (1995) applying the concept of reliability to a qualitative research method like participant observation finds that the posing of the following three questions are of great relevance:

1. Would we have seen the same and interpreted what we saw the same way if we had happened to have made the observation at another time?

This question deals with the stability of the observations.

2. Would we have seen the same and interpreted what we saw the same way if we had happened to pay attention to other phenomena during observation?

We may here speak of parallell form reliability. 
3. Would a second observer with the same theoretical framework have seen and interpreted the observations the same way?

We may here speak of objectivity or intra-judge subjectivity.

If we are not able to answer yes to such questions, it means that our data can be influenced by haphazard errors. Such haphazard errors may occur whether the data are reported through the use of numbers or in the form of verbal descriptions. The only difference is that if the data exist in the form of verbal descriptions, we cannot get an estimate put into numbers of the magnitude of the errors of measurement. It will still be of interest to get the information we can about reliability and if two independent researchers have been present we can at least compare verbal accounts or inter-pretations from each of the observers.

Haphazard errors may be present even if we have only one case under observation. Any observation, whatever type, contains errors of measurement. Feldt and Brennan (1989:105) remind us that we do not eliminate errors of measurement simply by ignoring them.

\section{Validity in qualitative research}

In the book about reliability and validity in qualitative research Jerome Kirk and Marc L.Miller (1986) differentiate between apparent validity,(when a measuring instrument is so closely linked to the phenomena under observation that it is "obviously" providing valid data) instrumental or criterion or pragmatic validity (when it can be shown that observations match those generated by an alternative procedure that is itself accepted as valid) and theoretical or construct or argumentative validity (when there is substantial evidence that the theoretical paradigm rightly corresponds to observations). Finn Tschudi (1988:121) quotes Ricoeur's contention that argument is primary in the social sciences, and not proof. The Norwegian educational researcher Tove Nagel (1992) who has done research on teacher training in Zimbabwe finds that the concept "argumentative validity" has to do with the whole research process and denies any abrupt short-cuts in methodological evaluation:

"I see the notion of argumentative validity as the eventual legitimatory force by which any research must stand court." (Nagel, 1992:153)

Construct validity and convergent validity are entailed in argumentative validity.

Other authors differentiate between internal validity (how correct the research portrays the phenomenon it is supposed to portray) and external validity (to what extent the findings can be generalized to other environments that are similar to the environments where the research was first 
carried out)

A conventional way of treating validity in qualitative research is the recourse to triangulation. Campbell and Fiske (1959) contend that what they coin as convergent validity implies that different methods for the same construct should give relatively high intercorrelation, while discriminant validity implies that similar methods for different constructs should give relatively low intercorrelation.

In an article on validity after poststructuralism Patti Lather (1993) postulates four postmodernist kinds of validity. She sees it as her task to think a way out of the validity discourses premised on correspondence theories of truth.

In a recent article "the Validity of Angels" Patti Lather (1995) again attempts to move the discussion of validity from epistemological criteria of truth as correspondence between thought and its object to criteria grounded in the crisis of representation. The article explores textual possibilities for telling stories that belong to others. She finds that the concept of "troubling angels" is the one which can best be used as a tool for analysis of the stories told her from women living with AIDS. The article discusses how she arrived at this concept:

"Across multiple differences of race, class, age, and health, the women seemed angels in their love for one another and in their wanting to be "messengers" to other women about HIV/AIDS. Not too much later, as I puzzled over how to situate myself in relation to the women, the concept of standing with impressed itself upon me, which segued into standing with angels and a world opened up." (Lather,1995:47)

She also finds poems and text about angels, pictures, paintings which give meaning to her text. When I read the article, I thought that maybe the spirits in Africa - the wazimu - could provide a similar tool of analysis for text from the living experience of Africans.

The aim of critical researchers, according to Joe L.Kincheloe and Peter L.McLaren (1994) is to attempt to move beyond assimilated experience and to confront the way power reproduces itself in the construction of human consciousness. They embrace the notion of catalytic validity first described by Patti Lather (1991). Catalytic validity points to the degree to which research moves those it studies to understand the world and the way it is shaped in order to transform it.

Research that possesses catalytic validity will not only display the reality-altering impact of the inquiry process, it will also direct this impact so that those under study will gain self-understanding 
and self-direction.

This concept comes close to the concept of validity-as-relevance/advocacy (VAR) (Altheide and Johnson, 1994) which stresses the utility and "empowerment" of research to benefit and uplift those groups often studied - relatively powerless people, such as the poor, or peasants.

We shall here devote some more space to the concept of external validity even though the concept, according to Egon G.Guba and Yvonna Lincoln (1994) in their article on "Competing Paradigms in Qualitative Research" belongs more to the positivist or postpositivist paradigm. They write about the inquiry aims of the constructivist paradigm which are oriented to the production of reconstructed understandings, wherein the traditional positivist criteria of internal and external validity are replaced by the terms trustworthiness and authenticity.

\section{External validity including ecological validity.}

Graham Vulliamy (1990) stresses that different emphasis is given within the qualitative and quantitative paradigm concerning their relative attention to various aspects of external validity. External validity refers to the extent to which findings from research can be usefully generalized. In positivist research traditions, and especially in social survey analysis, this problem has been seen largely in terms of sampling strategies in order to ensure that the people studied are representative of the wider population to which generalizations are desired.

However, there is a second component of external validity which is often discussed in connection with threats to the external validity of experiments. This component is called ecological validity. This concerns the extent to which behaviour observed in one context can be generalized to another.

For many qualitative researchers in education the maximization of ecological validity is one of the many rationales of their approach. The problem with more traditional research methods, such as questionnaires and experiments, is that they are unlikely to give an accurate portrayal of the realities of teaching in a natural or conventional setting. Questionnaire surveys cannot penetrate the gap between "words and deeds". The strictures of experimental design are such that only rarely does the setting approximate to the realities of "normal" schooling to which generalizations need to be made.

\section{Ecological validity of case studies at a school level.}

There has been a tendency for the literature on education in developing countries to be concerned more with a discussion of policies and system-wide features than with what Michael Crossley and Graham Vulliamy (1984) call "observations of the realities of schooling at the chalk face." 
One of the main contributions of a qualitative research strategy lies exactly in focusing on the actual implementation of policies in schools and thus assessing the points at which policy and practice converge and diverge. The kinds of evaluation methods that have been used most frequently in developing countries sometimes make it difficult to penetrate any marked divorce between policy and practice. Questionnaires have a tendency to reproduce the rhetoric of policies. So also do brief factfinding visits to schools, another very common method of evaluation, especially by donor agencies and international organizations operating in developing countries. (Vulliamy,1990)

Where substantial and rigorous research evaluations of educational policies and innovations in developing countries have been conducted, they have nearly always utilized the traditional quantitative input-output research design. This is especially the case with the larger World Bank studies. The results of such research assume that the adopted policy is actually implemented and, secondly, that this process of implementation corresponds to the policy directive itself. A useful illustration of this is a major World Bank evaluation of the diversification of secondary schooling in Colombia and Tanzania (Psacharopolous and Loxley,1985). For the Tanzania data, the statistical analysis was based upon comparisons of students from their designated curriculum biases. However research of a more qualitative nature being undertaken by Tanzanian researchers showed that, not only did the official bias often not correspond to the actual one (a fact that principals might not be prepared to disclose in their response to the questionnaires in the World Bank study) but also that the policy was not actually implemented in many secondary schools. (Lema, 1972, Besha,1973, Muganyizi, 1976, Mblinyi,1976, Manase,1978)

All institutions, including schools, are characterized by a hierarchy of credibility. Organizations and communities are internally differentiated, where the interests of subgroups differ. However, within any system of ranked groups

"participants take it as given that members of the highest group have the right to define the way things really are" Becker,1970b:126)

Moreover, since institutions rarely work exactly as intended and contain conflicting interest groups, a research report that gives any credence to perspectives at variance from those from the top of the hierarchy of credibility will be seen as threatening. Thus Howard Becker argues that "even to say factions exist may upset the faction in control" (Becker, 1970a:111). He concludes that "a good study will make somebody angry" (1970a:113). Vulliamy (1990:109) tells from his own research in Papua New Guniea that one SSCEP (Secondary Schools Community Extension Project) coordinator, who was highly committed to the innovation, was upset that he should take seriously the perspectives of 
staff who were not. Also presenting a school's eye view of SSCEP to the national Headquarters team was inevitably threatening where it was apparent that aspects of the project were not working as intended.

In order to assure high ecological validity it is necessary that as many characteristics as possible about the school in question are given. This means the number, training, age, gender composition of the teaching staff, the number of students, subject combinations, grades, resources at disposal for the school and so on. But the more characteristics are given for each school the easier it gets to recognize the school and the more difficult it gets to secure the anonymity some schools would like to have. This is a question I discuss at great length in a book I have written comparing three different secondary schools located in the same socio-economic environment and having the same resources but adhering to different forms of leadership and cooperation. (Brock-Utne,1980) Especially when the description in one case seemed threatening to the leadership of one of the schools he wanted me primarily to drop the whole case study of his school or as an alternative to write in such a way that none, not even those working in the school, would be able to recognize the description. In that case the ecological validity would be so low - one might claim I was writing fiction.

When it comes to the example of the experiences of living with albino children in Sub-Saharan Africa we may say that the auto-biographical description has high ecological validity since it is very likely that the three categories of problems experienced by my colleague would also be experienced by other black parents of albino children in Sub-Saharan Africa. In an autobiographical approach like in a case-study approach anonymity will be hard to uphold. Yet these approaches may be those most needed in African educational research to-day. To assure reliability of auto-biographical approaches it may be wise to compare the auto-biographies for instances of two black African mothers with albino children. If we find the description of the problems they encounter rather similar, we may say that the research method used has high reliability as well as validity.

\section{References}

Abu-Loghod, Lila, 1991: Writing against Culture. In: Fox (ed): Recapturing Anthropology. School of American Research Press.

Becker,Howard 1970a: Problems in the publication of field studies. In: Sociological Work. New Brunswick, New Jersey: Transaction Books.

Becker,Howard 1970b: Whose side are we on? In: Sociological Work. New Brunswick, New Jersey: Transaction Books. 
Besha,M. R. 1973: Education for Self-Reliance and rural development. (mimeo) Dar es Salaam: Institute of Education.

Brannen, Julia (ed.)1992: Mixing Methods: Qualitative and Quantitative Research. Aldershot: Avebury.

Brock-Utne, Birgit, 1980: Ungdomsskoler i utvikling. (Innovation in secondary schools) Oslo: Universitetsforlaget.

Brock-Utne, Birgit,1994: (ed.) Indigenous forms of learning in Africa. Education in Africa. Vol.2. Rapport no.7.1994. 160 pp. Oslo: Institute for Educational Research.

Callewaert, Staf,1994: Are African Pupils Different? Paul Riesman's Contribution to Ethnopedagogics. In: Schnack, Karsten, 1994 (ed.): Export of Curriculum and Educational Ideas. Didaktiske studier. Studies in Educational Theory and Curriculum. Vol.14. Copenhagen: Royal Danish School of Eductional Studies.pp.99-129.

Campbell, D.T. and Fiske, D.W.1959: Convergent and discriminant validation by the multitraitmultimethod matrix. Psychological Bulletin. Vol.56.pp.81-105.

Cronbach, L.J. and Meehl, P.E.1955: Construct validity in psychological tests. Psychological Bulletin. 52. pp.281-302.

Crossley, M. and Vulliamy, Graham. 1984: Case-study research methods and comparative education. Comparative Education. 20. pp.193-207.

Denzin, Norman K \& Lincoln, Yvonna S.(ed.) 1994: Handbook of Qualitative Research. Beverly Hills, Ca.: Sage Publications

Feldt, Leonard and Robert Brennan, 1989: Reliability. In: Linn, Robert(ed.): Educational Measurement. 3.ed. New York: Macmillan. 105-146.

Finnegan,R. 1970. Oral Literature in Africa. Oxford: Claredon Press.

Guba,Egon G. and Yvonna Lincoln, 1994: Competing Paradigms in Qualitative Research. In:Denzin, Norman K \& Lincoln, Yvonna S.(ed.) 1994: Handbook of Qualitative Research. Beverly Hills, Ca.: Sage Publications. pp.105 - 117.

Hammersley, Martyn, 1992: Deconstructing the qualitative-quantitative divide. In: Brannen, Julia 
(ed.)1992: Mixing Methods: Qualitative and Quantitative Research. Aldershot: Avebury. pp.39 - 57.

Ishengoma,J.M.R. 1988. Riddles as an agent of socialization and social learning among the Haya children. Term Paper for Ed.605:Social Psychology. University of Dar es Salaam:Faculty of Education.21.pp.

Kirk,J. \& Miller, M.L. 1986: Reliability and validity in qualitative research. Beverly Hills, Ca.: Sage Publications

Kincheloe, Joe L. and Peter L.McLaren, 1994: Rethinking critical theory and qualitative research. In: Denzin, Norman K \& Lincoln, Yvonna S.(ed.) 1994: Handbook of Qualitative Research. Beverly Hills, Ca.: Sage Publications. pp.138-158.

Kleven,Thor Arnfinn, 1995: Reliabilitet som pedagogisk problem. (Reliability as an educational problem) Mimeo. Doctoral lecture 17.February 1995. Oslo: Institute for Educational Research.

Kvale, Steinar,1989:To validate is to question. In: Kvale, Steinar,1989 (ed.):Issues of Validity in Qualitative Research. Lund: Studentlitteratur. 73-92.

Kvale, Steinar,1989 (ed.):Issues of Validity in Qualitative Research. Lund: Studentlitteratur. Lather, Patti,1991: Getting smart: Feminist research and pedagogy with/in the postmodern. New York: Routledge.

Lather, Patti,1993: Fertile obsession: Validity after poststructuralism. Sociological Quarterly. 34 (4) 673-693.

Lather, Patti,1995: The Validity of Angels: Interpretive and Textual Strategies in Researching the Lives of Women With HIV/AIDS. Qualitative Inquiry. Vol. 1. No.1.pp.41-68.

Lema, A.A. 1972: Education for Self Reliance. A Brief Survey of Self Reliance Activities in some Tanzanian Schools and College. Dar es Salaam: Institute of Education.

Manase,T.J.1978:Ideological state apparatus reproduces existing productive relations: The case of Mdanda educational institutions. In: Ishumi, Abel and Mmari, Geoffrey (eds): The Educational Process. University of Dar es Salaam: Department of Education.

Mblinyi,Majorie, 1976: The study of education and the "community". In:King,Kenneth (ed.): Education and Community in Africa. University of Edinburgh: Centre of African Studies. 
Miller, Janet, 1982: The Sound of Silence Breaking: Feminist pedagogy and theory. Journal of Curriculum Theory. 4 (1), 5 -11.

Muganyizi,L. 1976: Implementation and usefulness of Self-Reliance in schools: Findings of research carried out in Bukoba district. Papers in Education and Development. 2. pp.97-121.

Nagel, Tove,1992: Quality between tradition and modernity. Patterns of communication and cognition in teacher education in Zimbabwe. Doctoral Thesis. Oslo: Institute for Educational Research.

Ocitti, J.P. 1990. Indigenous Education for Today. The Necessity of the Useless. Adult Education and Development. No 35.:347 - 357. German Adult Education Association.

Pinar, William, 1995: Regimes of Reason and Male Narrative Voice. (mimeo)

Psacharopoulos, G and Loxley,W 1985: Diversified Secondary Education and Development: Evidence from Columbia and Tanzania. Baltimore: John Hopkins University Press.

Rand, Gunvor, 1971: Elementer testteori. Oslo: Universitetsforlaget. 3.edition.

Stanfield II,John 1994: Ethnic Modeling in Qualitative Research. In: Denzin, Norman K \& Lincoln, Yvonna S.(ed.)1994: Handbook of Qualitative Research. Beverly Hills, Ca.: Sage Publications.

Stewart,David,1984: Secondary Research, Information, Sources and Methods. Applied Social Research Methods Series. Vol.4. Beverly Hills/London/New Delhi: Sage Publications.

Stordahl, Vigdis 1994: Same i den moderne verden. Endring og kontinuitet i et samisk lokalsamfunn. (Sami in the modern world. Change and continuity in a Sami community) Karasjok.

Theal, G.M. 1910. History and Ethnography of Africa, South of the Zambezi before 1795. London: George Allen and Unwin.

Tschudi,Finn, 1989: Do qualitative and quantitative methods require different approaches to validity? In: Kvale, Steinar,1989 (ed.):Issues of Validity in Qualitative Research. Lund: Studentlitteratur. pp.109-135.

Vulliamy,Graham, Keith M. Lewin and David Stephens, 1990: Doing Educational Research in Developing Countries: Qualitative Strategies. London: The Falmer Press.

Vulliamy,Graham, 1990: The Potential of Qualitative Educational Research Strategies in Developing 
Countries. In: Vulliamy,Graham, K.M. Lewis and D.Stephens, 1990: Doing Educational Research in Developing Countries: Qualitative Strategies. London: The Falmer Press. pp.7-25.

Østerud, Svein, 1995: Relevansen av begrepene "validitet" og "reliabilitet" i kvalitativ forskning. (The relevance of the concepts "validity" and "reliability" within qualitative research. Mimeo. Doctoral lecture 9.of June 1995. Oslo: Institute for Educational Research. 